\title{
Comments on Gunnar Larsen's publications
}

\author{
ARNE DINESEN \\ https://doi.org/10.37570/bgsd-1996-43-19
}

In connection with Gunnar Larsen's retirement from his chair at the Department of Geology, Aarhus University, Dr. Christian Kronborg compiled a list of the publications in which his old professor was involved, most often as an exclusive author and sometimes as a co-author. The list comprises no less than 153 items, and everybody who knows the recently retired profes-sor will also know that the list is going to be some-what longer. When this commentator received a cur-rent copy of the list, I became supremely overconfi-dent. I decided to read the professor's complete works from one end to the other. It is probably needless to say that I had to change my mind after some days of intensive absorption in a few of the said publications. The amount of text, tables, figures and plates is so enor-mous that a proper study of the total production could easily have taken several months. As a matter of fact I have to admit that my comments are based on reading just a fraction of the works produced by the diligent professor. Nevertheless, I am reasonably convinced that the selected ones are quite representative.

On the occasion of the 25th anniversary of the De-partment of Geology, Gunnar Larsen wrote a book (in Danish) on "Geology in Århus 1961-1986" (Larsen 1986). This book is interesting for several reasons. The vivid history of the department and the strong efforts spent during the years in education and research (some-times under labyrinthic conditions for housing) are described by use of a thoroughly prepared systematics and a concise mode of expression. These important and reader-friendly features are also prominent in his scientific production. However, unlike his scientific works, some passages of the anniversary-book are strongly seasoned by the professor's pronounced sense of dry humour (now and then pretty close to cutting satire). Furthermore, the book contains the outlines of a statement regarding his idea on a preferable scientific approach by saying (in my free translation): "As indicated under the comments on research activities at the department, there is a widespread inclination to attach great importance to the applied aspects of the profession. This is the situation of today but it may not always have been the case. At any rate, older colleagues may be able to remember that during their period of study - and obviously this means somewhere else than at the Department of Geology in Århus - it was not very "distinguished" to confess that one was interested in the practical applications of the profession. It has hardly been that bad at the Department of Geology but still it may be possible to sense that a drift to more heavy engagement in the possible applications of the science of geology occurred during the 25 years."

To put it mildly, the harmonization of several types of human activities compared to the circumstances offered by the nature, including its geological resources, still appears to be rather poor now 10 years after Gunnar Larsen made the statement quoted above. Therefore, it is difficult to find any sign of a decreasing need for practically inclined geoscientists.

To a great extent Gunnar Larsen himself has cultivated the applied aspects of geology. Disregarding the number of pages etc. of the specific papers, the 153 publications can be split up - sometimes arbitrarily as follows:

Papers generally concerned with sedimentological and stratigraphical topics (however, frequently of fundamental importance to the study of practical aspects): 21. - Specified: 13 papers deal with the Pre-Quaternary sequence, 8 papers with the Quaternary sequence.

Papers concerned with mineral resources: 26 . - Specified: 1 paper deals with concentrations of heavy minerals in recent Danish beach sand, 3 papers deal with potassium salt, 8 papers with conventional raw materials like sand and gravel, 14 papers with building materials (most often the suitability of gravel as a component of concrete).

Papers concerned with (sub)soil investigations in preparation for various types of construction work: 15 . - Specified: 13 papers deal with bridges, tunnels etc., 2 papers with potential storage of radioactive waste.

Papers concerned with landscape planning/preservation: 10.

Papers in which imparting of knowledge (often about applied aspects of geology) is dominant: 81. - Specified: 11 papers are summaries of lectured papers, 7 papers are excursion reports or guidebooks, 18 papers represent editorial contributions to textbooks or other types of thematic books (not including various periodicals for which editorial work was rendered during several years), 18 papers represent efforts in popularization, 7 papers may be classified as "miscellaneous", 20 papers are book reviews. 
When I finished my reading of the very long list of publications, and also of a chosen few of the publications themselves, I felt sorry for him that he didn't have any spare time to waste on luxuries such as teaching. Therefore, a short time ago I asked one of the professor's former students: "How did you experience Gunnar Larsen as a teacher?". The former student (who never speaks without using his brain rather carefully as a first step) answered: "Excellent. You really felt that he put his body and soul into his lectures". It may not be an everyday occurrence that a professor's pedagogical display can provoke such an unreserved praise, and I strongly feel that his ability to animate the matter for his students is bound up with his own scientific commitment to a wide spectrum of practical tasks related to geology.

Ever since he was a young student himself, Gunnar Larsen has demonstrated a special flair for a quick and precise definition of a specified problem as well as for an effective processing of the relevant data and for a clear presentation of the achieved results. One example - and maybe the most extreme one - took place when he was forced to do his military service shortly after receiving his M.Sc. degree. I doubt that he enjoyed square-bashing or shooting very much. At any rate, he quickly succeeded in persuading the supreme command that he should concentrate his efforts on a study of the suitability of the varying nature of the Danish landscape to take military traffic. Of course, he provided the Danish Army with an instructive book on the subject (Larsen 1960) before he was demobbed some months later.

The character of "the landscape" - both the recent one and the previous, more or less deeply buried ones - appears to play a prominent role in Gunnar Larsen's overall conception of geology. The configuration of the landscape and the contents of the subjacent strata are "the documents" to which his deciphering efforts are tied in a great part of his works. Some of the usable characters of "the documents" occur as small grains of heavy minerals. Upon development and testing of the methodology on the Oligocene-Miocene Vejle Fjord Formation as well as on the recent sand of the Danish beaches and a Mesozoic section in the strait (Øresund) between Denmark and Sweden (without any "interrupting" fault as thought earlier, just a big flexure), he proceeded intensively with his studies on the small heavy grains, and an outstanding result was his doctoral thesis from 1966: "Rhaetic-Jurassic-Lower Cretaceous Sediments in the Danish Embayment" (Larsen 1966). The chapter in which he discusses the reasons for the observed mineral distribution - by considering the effects coming from diagenetic and depositional processes in the sedimentary basin, the effects of transporting and the effects of weathering stepwise back to the composition of rocks in the source area - is in my mind a textbook example of clear and logical thinking. At the same time, the reader of the thesis is given a well-argued conception on "the landscapes" in which the events took place.

In contrast to the situation in more mountainous areas, it is relatively easy to work the recent Danish landscape by means of excavators and similar devices. Therefore, activities such as roadmaking, comparable types of construction projects, excavation of gravel etc. do not always inspire thoughtful planning concerning the landscape in which the mesh in question is projected. As evidenced from the list of publications, for 20 years or more Gunnar Larsen has spent persistent efforts in explaining the history behind exposed landscapes. The outcome is, at least here and there in Jutland, that there are several examples of a more gentle administration of the surface of the globe than originally planned by the most dynamic type of users.

Among the numerous efforts spent by Gunnar Larsen in the difficult branch of imparting of knowledge, also to non-specialists, a specific book deserves to be pointed out. In 1994, he and Christian Kronborg wrote a book (in Danish) in which the most interesting geological areas and outcrops of the central part of Jutland are perfectly described and illustrated (Larsen \& Kronborg 1994). This book is no less than a printed edition of a publicly available treasure.

\section{References}

Larsen, G. 1960: Terrængeologi for Ingeniørtropperne. Tidsskrift for Ingeniørofficerer. $1 \& 2$. (Tillige udsendt af Generalinspektøren for ingeniørtropperne som reglement. 51 pp.).

Larsen G. 1966: Rhaetic-Jurassic-Lower Cretaceous sediments in the Danish Embayment. A heavy-mineral study. Danmarks Geologiske Undersøgelse, II. Rk. 91.127 pp.

Larsen, G. 1986: Geologi i Aarhus 1961-1986. Aarhus Universitetsforlag. $120 \mathrm{pp}$.

Larsen, G. \& Kronborg, C. 1994: Geologisk set. Det mellemste Jylland. En beskrivelse af områder af national geologisk interesse. Geografforlaget \& Miljøministeriet, Skov- og Naturstyrelsen. $272 \mathrm{pp}$.

Arne Dinesen, Danmarks og Gronlands Geologiske Unders $\phi$ gelse, Thoravej 8, DK-2400 Copenhagen. 